\title{
Disease Resistance: What's Brewing in Barley Genomics
}

Cereal crops pose a substantial challenge to gene discovery. Except for rice and sorghum, most have large, complex genomes, the bulk of which consist of repetitive sequences and retrotransposons $(7,53)$. Thus, much of the early research relating to the molecular study of plant disease resistance has occurred in species with small genomes, such as Arabidopsis, rice, and tomato. The knowledge acquired from these model species has facilitated similar efforts in cereal crops. The goal of this report is to summarize the current tools available and to outline selected examples where these tools have been useful for the investigation of disease resistance in barley (Hordeum vulgare L.). Because molecular investigations have focused primarily on fungal pathogens, they will be the subject of this review.

\section{Genetics of Resistance}

Genes in plants that mediate resistance to fungal pathogens frequently display characteristic gene-for-gene specificity, as originally described by Flor (18). There are many resistance $(R)$ genes in plant hosts, each conferring unique interactions with particular pathogen isolates with corresponding avirulence $(A v r)$ genes. These $R$ genes often are organized as complex gene-families that are clustered on a particular chromosome. In general, $R$ genes function to recognize "elicitor" molecules produced by the invading pathogen. This

Dr. Wise's address is: USDA-ARS-Corn Insects and Crop Genetics Research Unit, Department of Plant Pathology, Iowa State University, Ames 50011-1020; E-mail: rpwise@iastate.edu

Names are necessary to report factually on available data; however, the USDA neither guarantees nor warrants the standard of the product, and the use of the name by USDA implies no approval of the product to the exclusion of others that may also be suitable.

Publication no. D-2000-0901-01F

This article is in the public domain and not copyrightable. It may be freely reprinted with customary crediting of the source. The American Phytopathological Society, 2000. recognition results in a rapid signal cascade, leading to an active defense response $(10,47) . \quad R$ genes and their associated physiological responses are exploited by plant breeders to offset yield loss caused by pathogen infection (Fig. 1). However, mutations occurring within dynamic pathogen populations can prevent the host's $R$ genes from recognizing the invading pathogen. The selection pressure for mutations within pathogen populations is exacerbated by the uniform planting of high-yielding varieties over millions of hectares in modern cropping systems. Because the primary means of disease control in cereals is through incorporation of genetic resistance into commercial varieties, current research on the fundamental signaling mechanisms that govern these interactions is leading to new methods of disease control (11).

Unique interactions among host resistance determinants and their corresponding pathogen isolates have been exploited for the analyses of several resistance gene clusters, and many laboratories have successfully cloned resistance genes from a variety of plant species $(13,48,51)$. Although the isolated genes confer resistance to a diverse range of pathogens, those historically defined by gene-for-gene interactions share various conserved amino acid sequences (Fig. 2). These include a serinethreonine protein-kinase domain, a coiledcoil domain (CC) or leucine zipper (LZ), a toll and interleukin-like receptor domain (TIR), a nucleotide-binding site (NBS), and leucine-rich repeats (LRR). The most prevalent class of cloned plant resistance genes contains a nucleotide-binding site combined with various lengths of a leucine-rich repeat. The NBS-LRR encoding genes are divided into two general subclasses, distinguished by the presence of a CC (LZ) or TIR 5' sequence, and are predicted to encode intracellular proteins $(48,51)$. There also is substantial evidence that the LRR is involved in recognition specificity. However, despite these genetic and molecular similarities, the cellular and biochemical mechanisms that lead to host plant resistance are diverse and largely unknown (5). Thus, various new technologies are being utilized to decipher these mechanisms for use in crop improvement.

\section{Discovery and Cloning of Disease Resistance Genes}

Genes encoding early signaling events in disease defense often are recognized only by their phenotype. Thus, given the size of the barley genome $(5,000 \mathrm{Mb})$, it is a substantial challenge to isolate these genes at the molecular level. However, there are other significant advantages to working with barley as a model for the small-grain Triticeae crops. Barley is a true diploid that is closely related to rice, rye, the cultivated tetraploid and hexaploid wheats, and diploid and hexaploid oat. Therefore, knowledge derived from gene discovery in barley is applicable to other small grains as well. In May 2000, there were over 400 cultivars and germ plasm accessions listed in the USDA-GRIN (Germplasm Resources Information Network) database and 24,998 accessions of Hordeum vulgare subsp. vulgare at the USDA National Small Grains Collection (NSGC) at Aberdeen, ID (http://www.ars-grin.gov/npgs/aberdeen. html). Also included at the NSGC are an additional 1,943 accessions encompassing 30 other Hordeum species and subspecies, including 161 from Hordeum bulbosum and 1,504 Hordeum vulgare subsp. spontaneum. These germ plasm holdings are a rich source of valuable genetic material. The challenge, therefore, is to identify and isolate genes from these sources that encode important agronomic traits for use in cultivar improvement. Two currently practiced methods for molecular isolation of genes recognized by their phenotype are transposon tagging $(9,68)$ and positional cloning or chromosome walking $(45,62,70)$. These two approaches have been widely used in many plant species.

Transposon tagging. The Ac (Activator)/ Ds (Dissociation) transposon system from maize has been introduced into other plant species by transformation and is an efficient tool for molecular isolation of genes with insertion mutations. Employing the inserted $A c$ or $D s$ elements as molec- 


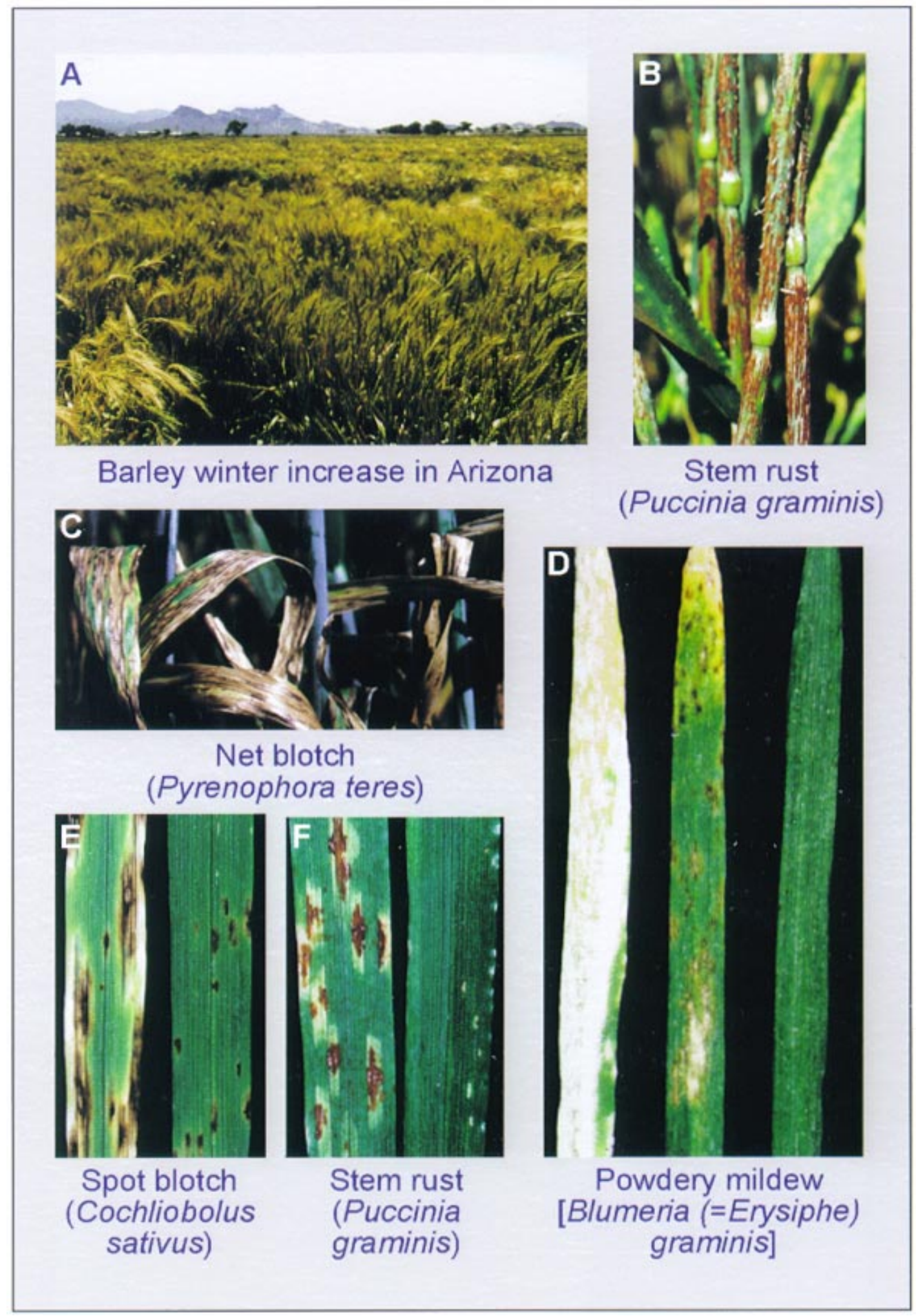

Fig. 1. Targets for isolation of fungal disease resistance in barley. (A) Healthy field of barley during Arizona winter season. (B) Barley plants infected with stem rust (Puccinia graminis f. sp. tritici) in the field (photo courtesy B. J. Steffenson, North Dakota State University). (C) Barley plants infected with net blotch (Pyrenophora teres f. sp. teres) in the field (courtesy of B. J. Steffenson). (D) Powdery mildew reaction of near-isogenic lines with different specificities conferred by the Mla locus to isolate A27 of Erysiphe graminis f. sp. hordei. C.I. 16152 (susceptible) carries a recessive mla allele; C.I. 16151 (intermediate resistance) carries the Mla14 allele; and C.I. 16155 (resistant) carries the Mla13 allele. (E) Differential spot blotch reaction of the doubled haploid lines Steptoe (susceptible) and Morex (resistant) to isolate ND85F of Cochliobolus sativus (courtesy B. J. Steffenson). (F) Differential stem rust reaction of the near-isogenic lines containing recessive and dominant alleles of the Rpg1 resistance locus to pathotype MCC of $P$. graminis f. sp. tritici. 80-tt-30 (susceptible) carries rpg1, and 80-TT-29 (resistant) carries Rpg1 (courtesy J. D. Miller, Cereal Crops Research, USDA-ARS, Fargo, ND). 
ular probes, this system has been used to clone a variety of genes in different plant species (43). As shown in Figure 3, an efficient transposon system for barley has been developed that utilizes the maize Ac/Ds complex (44). Stable, transformed plants carry one of two system components: (i) a $D s$ element containing the BAR gene, which encodes a phosphinothricin acetyltransferase enzyme, or (ii) the $A c$ transposase gene. The BAR gene is used as a selectable marker by conferring resistance to bialaphos or phosphinothricin. Plants containing the $D s$ element are crossed with plants carrying the $A c$ transposase gene and selfed. $F_{2}$ progeny then are screened for evidence of transposition using either DNA-blot hybridization with a $D s$-element probe or a polymerase chain reaction (PCR) assay for empty $D s$-donor sites (37). These assays were used in lieu of resistance to bialaphos or phosphinothricin because the transposition frequency is high and transgene inactivation

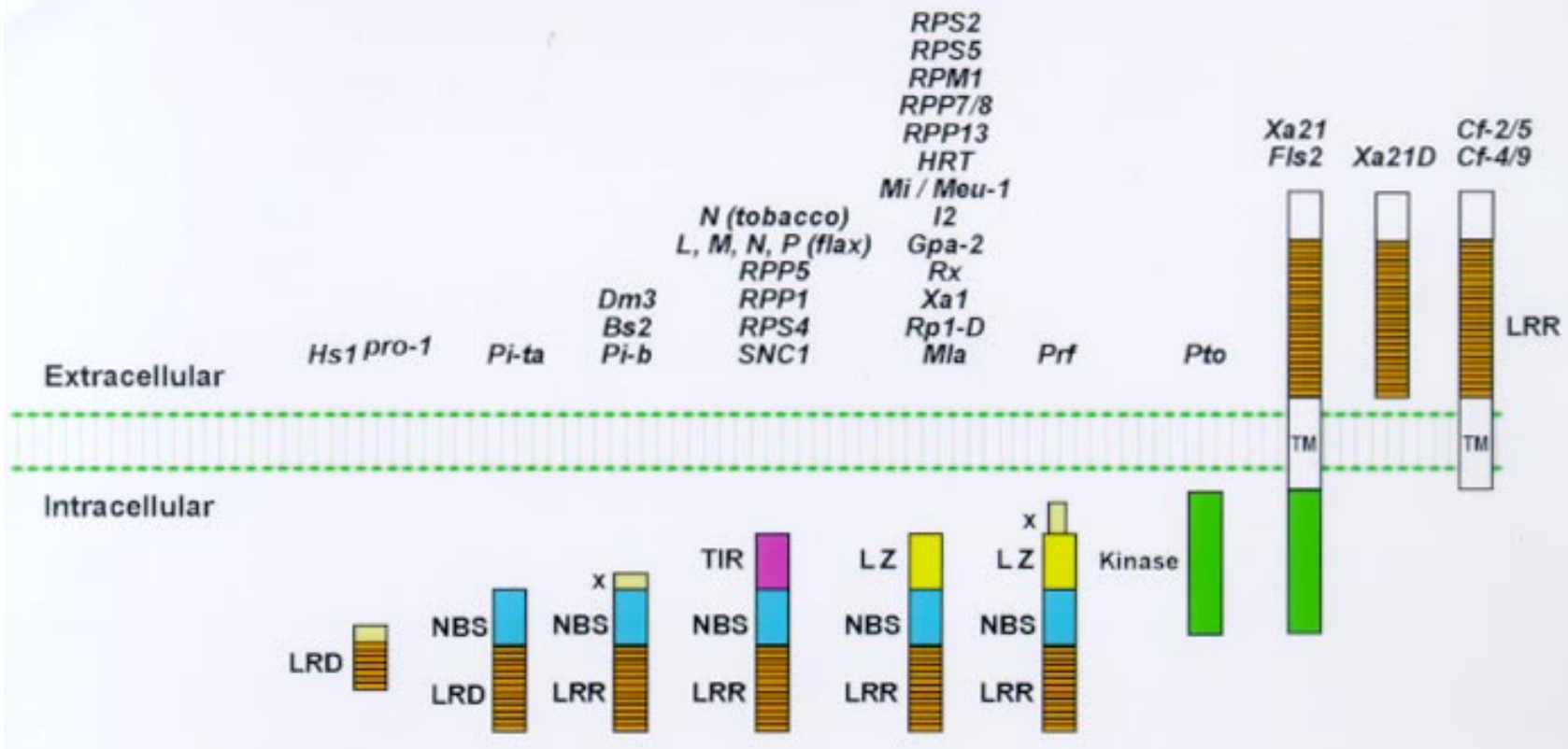

\begin{tabular}{|c|c|c|}
\hline \multicolumn{2}{|c|}{ Domain structure } & \multirow[b]{2}{*}{ Sugarbeet: Resistance to Heterodera schacheli } \\
\hline Hst prot & $x-L R D$ & \\
\hline Pi-ta & NBS-LRD & Rice: Resistance to Magnaporthe grisea \\
\hline $\begin{array}{l}\text { Dm3 } \\
\text { Bs2 } \\
\text { Pl-b }\end{array}$ & NBS-LRR & $\begin{array}{l}\text { Lettuce: Resistance to Bremia lactuca } \\
\text { Pepper: Resistance to Xanthomonas campestris } \\
\text { Rice: Resistance to Magnaporthe grisea }\end{array}$ \\
\hline $\begin{array}{l}N \\
\text { L,M, N,P } \\
\text { RPPS } \\
\text { RPP1 } \\
\text { RPSA } \\
\text { SNC1 }\end{array}$ & TIR-NBS-LRR & $\begin{array}{l}\text { Tobacco: Resistance to tobacco mosaic virus } \\
\text { Flax: Resistance to Molampsora lini } \\
\text { Arabidopsis: Resistance to Peronospora parasitica } \\
\text { Arabidopsis: Resistance to P.parasitica } \\
\text { Arabidopsis: Resistance to Pseudomonas syringae } \\
\text { Arabidopsis: Resistance to P. syringae }\end{array}$ \\
\hline $\begin{array}{l}\text { RPS2, RPS5, RPM1 } \\
\text { RPP7/8 } \\
\text { RPP13 } \\
\text { HRT } \\
\text { Mi / Meu-1 } \\
\text { I2 } \\
\text { Gpa-2 } \\
\text { Rx } \\
\text { Xat } \\
\text { Rp1-D } \\
\text { Mila }\end{array}$ & LZ-NBS-LRR & $\begin{array}{l}\text { Arabidopsis: Resistance to P. syringae } \\
\text { Arabidopsis: Resistance to P. parasitica } \\
\text { Arabidopsis: Resistance to P. parasitica } \\
\text { Arabidopsis: Resistance to turnip crinkle virus } \\
\text { Tomato: Resistance to Meioldogyne incognita } \\
\text { \& Macrosiphum euphorbiae } \\
\text { Tomato: Resistance to Fusarium oxysporum } \\
\text { Potato: Resistance to Globodera pailida } \\
\text { Potato: Resistance to potato virus X } \\
\text { Rice: Resistance to Xanthomonas oryzae } \\
\text { Maize: Resistance to Puccinia sorghi } \\
\text { Barley: Resistance to Erysiphe graminis }\end{array}$ \\
\hline Pto & Kinase & Tomato: Resistance to P. syringae \\
\hline Prt & $x-L Z-N B S-L R R$ & Tomato: Required for Pto-mediated resistance \\
\hline $\begin{array}{l}\text { Xa21 } \\
\text { Fis2 }\end{array}$ & LRR-Kinase & $\begin{array}{l}\text { Rice: Resistance to } X \text {. oryzae } \\
\text { Arabidopsis: Bacterial fiagellin recognition }\end{array}$ \\
\hline $\begin{array}{l}X a 21 D \\
C T-2 / 5 \\
C P=4 / 9\end{array}$ & LRR & $\begin{array}{l}\text { Rice: Resistance to } X \text {. oryzae } \\
\text { Tomato: Resistance to Cladosporium fulvum }\end{array}$ \\
\hline
\end{tabular}

Fig. 2. Conservation of resistance $(R)$ gene organization is illustrated by the different classes of cloned resistance genes. Conserved domains are designated kinase for "serine-threonine protein-kinase domain," TM for "trans-membrane domain," LZ for "leucine zipper," TIR for "toll and interleukin-like receptor domain," NBS for "nucleotide-binding site," LRR for "leucine-rich repeat," and LRD for "leucine-rich domain." 
in barley can be problematic. Up to $47 \%$ of the progeny showed evidence of $D s$ transposition, with $75 \%$ of these transpositions inserting at linked locations (T. Koprek and P. G. Lemaux, personal communication). Because, in other species, Ds elements are known to transpose preferentially to linked sites, constructing the appropriate plant populations with $D s$ elements closely linked to the gene of interest would make screening for disease-susceptible, insertion mutants more efficient than relying on random transposition. With mapped $D s$ elements, this method becomes a useful tool for generating the plant populations needed to isolate genes involved in disease defense.

Molecular markers. There are three basic requirements for map-based gene isolation: (i) a high-resolution, high-density genetic map spanning the target gene; (ii) availability of a large-insert genomic yeast artificial chromosome (YAC) or bacterial artificial chromosome (BAC) library; and (iii) multiple independent mutant stocks or an efficient transformation system for use in functional complementation. Recently, all of these resources have become available for barley as well as other cereal crops. In the following sections, the reader is directed to the glossary (Sidebar) for further explanation of terms.

Although barley has an extensive genetic map with over 1,500 molecular markers (35), this marker resolution is roughly the equivalent of knowing what state or county your friend lives in, but not knowing the city, street, or address. Thus, individual high-resolution maps that contain these "street addresses" must be developed to isolate genes of agronomic importance. One of the most efficient methods to develop DNA markers for a specified area of the genome is through the use of amplification fragment length polymorphism (AFLP), a powerful technique for DNA fingerprinting $(6,63,67)$. Using AFLP, one can detect up to 10 times as many polymorphisms as with standard restriction fragment length polymorphism (RFLP) analysis and up to 6 times more polymorphisms than with random amplified polymorphic DNA (RAPD) analysis. The main advantage of AFLP is that it is possible to differentiate up to 100 amplified DNA fragments on a single polyacrylamide gel. With AFLP technology, populations segregating for resistant and susceptible plants can be utilized in a pooling strategy known as bulk-segregant analysis to generate multiple, tightly linked DNA markers $(22,49)$. Additionally, diseasesusceptible deletion mutants can be compared with their progenitors via a genomewide AFLP scanning strategy (45).

Sequence-specific amplification polymorphism (S-SAP) is an adaptation of AFLP that is useful for the development of additional molecular markers. The S-SAP method utilizes a gene-specific primer paired with random AFLP primers to amplify fragments of particular gene families. These genes could be candidates involved in defense signaling or an endogenous class of repetitive elements, such as retrotransposons. For example, there are at least $3 \times 10^{4}$ copies of the Tyl-copia-like Bare-1 retrotransposon in barley, which is equivalent to $6.7 \%$ of the genome $(61,66)$. Therefore, when a Bare-1 long terminal repeat (LTR) primer is paired with random primers, S-SAP polymorphisms can be detected due to retrotransposon-specific variations $(69,71)$. A $25 \%$ increase in the rate of polymorphism has been observed with retrotransposon-based S-SAP compared with standard AFLP $(38,69)$. Hence, AFLP- and S-SAP-based approaches produce an abundance of amplified polymorphisms that have been successfully used in genomic fingerprinting, gene targeting, and genome mapping $(6,67,69)$.

Isolation of resistance gene analogs via a conserved domain strategy. As described above, there appears to be significant similarity among the conserved amino acid sequences within different classes of cloned resistance genes. Thus, it is possible to derive various PCR primers corresponding to these domains to amplify portions of resistance gene-like sequences. The serine-threonine protein kinase, NBS, and LRR domains have been the most utilized for this purpose $(29,41,72)$. Nucleotide sequences that have been amplified with these primers have been desig- nated resistance gene analogs (RGA) or resistance gene homologs (RGH). RGA (RGH) probes have been used to screen large-insert BAC libraries to identify the genomic regions containing putative disease resistance genes (73). Because resistance-gene families usually are organized as complex clusters, at present these amplified RGA (RGH) sequences have corresponded to the desired $R$ gene in only a few systems $(9,45)$. In both of these cases, disease-susceptible insertion or deletion mutants have been the key to this identification. Nevertheless, by combining a series of these tools, such as AFLPs and RGAs, with a robust large-insert (BAC or YAC) library, large resistance-gene families can be identified on a single contiguous DNA region (70).

Utilizing an S-SAP strategy, it is possible to pair conserved resistance-gene domain primers with random AFLP primers to generate RGA-AFLPs. This strategy could use as a template either genomic DNA pools derived from a segregating population or a series of overlapping BAC clones that span the target region. Because the resistance-gene primer is paired with a random primer, this assay is not dependent upon using two conserved domain primers to generate an amplification product. Since previously characterized resistance genes often have different combinations of the serine-threonine protein kinase, CC (LZ), TIR, NBS, or LRR domains, a prior knowledge of the gene structure is not
A

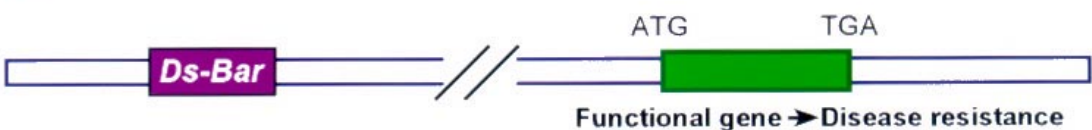

Functional gene $\rightarrow$ Disease resistance
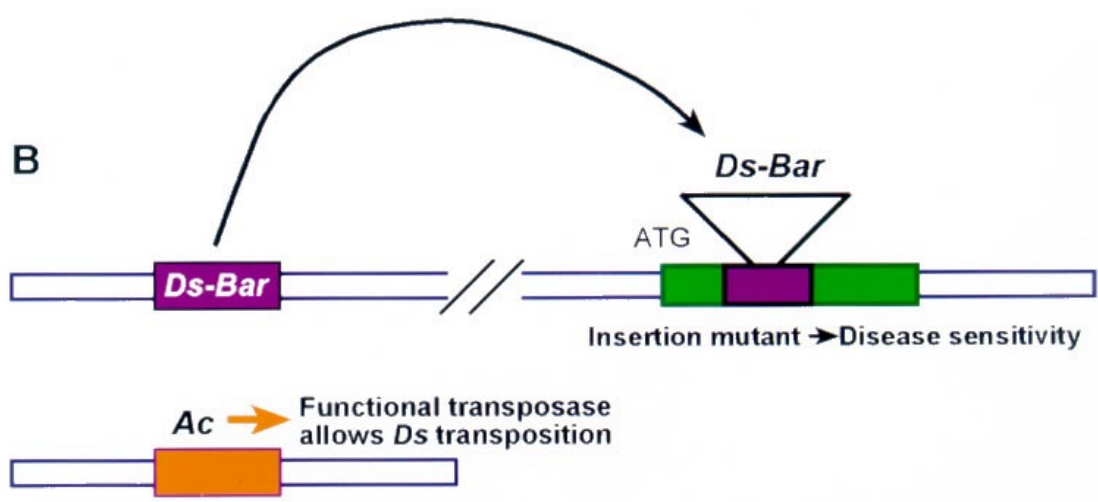

Fig. 3. Transposon tagging resistance $(R)$ genes with the engineered maize $A C$ (Activator)/Ds (Dissociation) system. (A) In the absence of the Ac transposase, Ds elements are stable and remain inserted at their original location. (B) When a chromosome containing the $A c$ element is combined in the same plant with a chromosome containing the $D s-B a r$ insertion element, the $A c$-encoded transposase functions to promote $D s$ element excision and insertion into a new position. Ds elements preferentially transpose to linked locations; however, Ds can move to unlinked locations at a lower frequency. If $D s$ is inserted into a resistance gene, the resistance would be predicted to be nonfunctional, and these novel plants can be detected by sensitivity to the respective pathogen. In turn, the cloned Ds element can be used as a molecular probe to facilitate isolation of the resistance gene. 
necessary. Therefore, by pairing a single domain primer with a random AFLP primer, the chances of amplifying an RGAlike sequence are increased.

The use of messenger RNA as a tem- plate instead of genomic DNA can further refine the S-SAP strategy. The cDNAAFLP method utilizes mRNA populations from different treatments or genotypes as a template for AFLP analysis (4). Hence,
mRNA can be isolated from the same segregants derived from a mapping population to create pools of expressed sequences from resistant and susceptible plants. Those same pools can be used as a tem-

\section{Glossary}

\section{Common molecular biology acronyms}

AFLP: Amplified Fragment Length Polymorphism is a powerful marker class, allowing rapid and simultaneous evaluation of 50 to 70+ potentially polymorphic sites. AFLP is well adapted to linkage mapping and diversity assessment and is primarily dominant in nature.

BAC: Bacterial Artificial Chromosome; these clones contain DNA inserts that are about $120 \mathrm{~kb}$.

BSA: Bulk Segregant Analysis is a method to rapidly identify markers in specific regions of the genome. The method involves comparing pooled DNA samples of individuals from a segregating mapping population or recombinant inbreds. Within each pool, individuals are identical for the target sequence but are heterogeneous for all other sequences. In this way, pools of DNA from plants that differ for a particular trait, such as disease resistance or susceptibility, can be analyzed to identify polymorphic markers associated with the trait.

cDNA-AFLP: utilizes mRNA populations from different treatments or genotypes as a template for AFLP analysis.

GFP: Green Fluorescent Protein from the jellyfish Aequorea victoria is a reporter molecule for monitoring gene expression and protein localization. GFP fluoresces bright green upon exposure to UV or blue light.

PCR: Polymerase Chain Reaction.

RAPD: Random Amplified Polymorphic DNA utilizes a single 10-nt primer to amplify DNA via PCR.

RGA: Resistance Gene Analog (see text).

RGH: Resistance Gene Homolog.

RGA-AFLP: Resistance Gene Analog AFLP employs conserved resistance-gene domain primers with random AFLP primers to amplify resistance gene-like regions.

RFLP: Restriction Fragment Length Polymorphism is a technique in which organisms may be differentiated by analysis of patterns derived from cleavage of their DNA.

S-SAP: Sequence-Specific AFLP Polymorphism utilizes a genespecific primer paired with random AFLP primers to amplify fragments of your favorite gene family.

YAC: Yeast Artificial Chromosome; these clones contain DNA inserts that can average 200 to $300 \mathrm{~kb}$; however, they are often chimeric and may be unstable.

\section{Amino-acid domain abbreviations for cloned resistance genes}

CC: Coiled-Coil; an amino acid sequence with the potential to form coiled-coil protein structures. Some members of the coiled-coil sequence have conserved amino acids in common with leucine zippers, a subtype of coiled-coil domains. Therefore, CC-NBS-LRR proteins sometimes have been designated LZ-NBS-LRR proteins.

LRD: Leucine-Rich Domain.

LRR: Leucine-Rich Repeat.

LZ: Leucine Zipper.

NBS: Nucleotide Binding Site.

TIR: Toll and Interleukin-like Receptor.

TM: Trans-Membrane Domain.

\section{Abbreviations for chemical terms}

kb: Kilobase, $1 \times 10^{3}$ bases.

kDa: Kilodalton.

Mb: Megabase, $1 \times 10^{6}$ bases.

\section{Definitions of general biotechnology terms}

Biolistic transformation: Method of transforming plant tissue with a particular gene(s) via particle gun bombardment.

Chromosome 5 (1H): Barley is a true diploid with a haploid chromosome number of 7 . The first number designates the historical chromosome designation in barley. The "\#H" designation is based on the Triticeae nomenclature, where the number is the syntenic wheat chromosome and the " $\mathrm{H}$ " is the designator for Hordeum.

Chromosome landing: Isolation of a YAC or BAC containing the target gene via the use of a DNA marker that is physically linked on the same clone.

Chromosome walking: Isolation of a clone containing the target gene by the use of overlapping YAC or BAC clones selected via the use of a tightly linked DNA marker.

cM: Centimorgan.

Computational analysis/Bioinformatics: In all gene-isolation projects, the DNA sequence is subjected to a comparative search of the available databases. Because genes that exhibit similar function often display conservation of amino acid domains, all available DNA and protein data, including whole genome sequencing projects for plants, animals, and microbes, are searched for clues to possible function of the unknown gene.

Contig: A contiguous DNA segment developed from a series of overlapping clones.

DNA marker: Any PCR- or hybridization-based assay that allows the pinpointing of a particular position on a genetic map.

EST: Expressed Sequence Tag-DNA sequence from part or all of an RNA message in a cell.

LTR: Long Terminal Repeat sequence.

$\mathbf{M}_{2}$ : Second generation of self-pollinated plants after mutagenesis.

MAS: Marker Assisted Selection. Normally, breeders go through lengthy analysis to identify the plants that contain specific traits before they can use them to improve particular varieties. MAS utilizes molecular markers to genotype the plants at the seed or seedling stage and selection is done before planting. For example, a desirable barley variety may possess resistance to fungal, viral, and bacterial diseases in addition to factors for agronomic performance. General use PCR-based markers can be used to screen these plants for the appropriate genotypes at the seedling stage instead of inoculating the entire breeding population with these different pathogens.

Microarray "Gene chip": With the invention of the DNA chip, researchers are now able to investigate 10,000 genes at a time. Tiny spots of DNA originating from these genes are spotted on a glass slide. This slide is hybridized with two contrasting fluorescently labeled cDNAs representing different "genetic states." With the aid of computer software, an investigator can measure the expression of thousands of genes simultaneously.

Polymorphism: A visible or molecular difference between two contrasting individuals.

Synteny: Conservation of marker order between large segments of chromosomes. Typically, closely related species such as barley, wheat, and rice share a high degree of conservation among chromosomes. The sections that share molecular marker conservation are syntenic. 
plate for RGA-cDNA-AFLP analysis to identify expressed sequences that cosegregate with the target gene.

Map-based strategies to clone genes involved in disease defense. Powdery mildew of barley, caused by Erysiphe (Blumeria) graminis f. sp. hordei, is an ideal system to investigate the molecular mechanisms regulating fungal resistance. Recently, genes have been cloned for nonspecific resistance (8), specific resistance (70), and resistance signaling (56). These efforts have led to new hypotheses regarding the molecular mechanisms of resistance to powdery mildew.

Approximately 30 variants of the Mla resistance-gene cluster on chromosome 5 $(1 \mathrm{H})$ have been differentiated by their specific reaction to unique isolates of $E$. graminis (27). In preparation for positional cloning of the Mla locus, AFLP-, RAPD-, and RFLP-derived markers were used to saturate the Mla region in a high-resolution recombinant population. These tightly linked genetic markers were used to identify and develop a contiguous DNA sequence of YAC clones from the cultivar Franka $(33,34)$ and BAC clones from the cultivar Morex (73). The DNA sequence of the Mla-spanning BAC clones was determined by shearing the BACs into smaller fragments, subcloning the fragments into a plasmid vector, and sequencing and assembling the clones, a strategy similar to those used in the Human Genome Project. Computational analysis of the sequence revealed an interspersed arrangement of three distinct NBS-LRR, RGH gene families (Fig. 4; 70).

The discovery of three dissimilar NBSLRR, RGH families that reside at the Mla locus is unique. In contrast, most cloned resistance genes are comprised of only one gene family. For example, the rice $\mathrm{X} a 21$ family, which confers resistance to Xanthomonas oryzae, and the tomato Cf2/Cf5 family, which confers resistance to Cladosporium fulvum, are both organized as single clusters of homologous genes $(14,15,59,60)$. Likewise, the lettuce Dm3 locus, which confers resistance to Bremia lactuca, and the Cf4/Cf9 locus of tomato both contain many related copies of resistance-gene homologues that are physically associated, yet are spread over several megabases $(2,45,46,50,55)$. Furthermore, the $L$ and $M$ gene families, which confer resistance to Melampsora lini, are highly similar but reside on different chromosomes $(1,40)$.

Investigation of disease resistance through mutations in host-pathogen interactions. Numerous investigations have targeted disease interactions via the use of mutations. Genomic technologies are strengthened through the use of mutant stocks as a starting point. There are over 900 published mutant descriptions in barley, and many more in unpublished but available collections (19). Two such mu- tants, Rarl and Rar2, define loci that are Required for Mla-mediated resistance $(21,27,64)$. Rarl and Rar2 are required for the function of many, but not all, powdery mildew interactions (28); these data provide evidence that there is more than one signaling pathway for the various $M l$ loci (Fig. 5). Rarl, located on chromosome 2 (2H), was cloned via high-resolution AFLP analysis and subsequent chromosome landing utilizing a YAC library from the cultivar Ingrid (39). Computational analysis of the Rarl sequence revealed that the gene encodes a putative zinc-finger protein that is likely to function in disease-resistance signaling. Comparison of proteins encoded by Rarl-like sequences among different phyla indicates that they possess a 60-amino acid domain, conserved in tandem organization in protozoa, plants, and metazoa. This domain has been designated CHORD (cysteine and histidine rich domains). Proteins that contain the CHORD domain may share cellular functions, suggesting that plant resistance genes may have recruited a conserved control element that is involved in resistance signaling (56).

The Rar2 locus appears to be tightly linked to Mla on chromosome $5(1 \mathrm{H})(\mathrm{P}$. Schulze-Lefert and R. P. Wise, unpublished results). It has been shown previously that NBS-LRR genes are physically adjacent to and required for the function of other resistance genes (52). The finding of three unrelated NBS-LRR, RGH families at the Mla locus is consistent with this

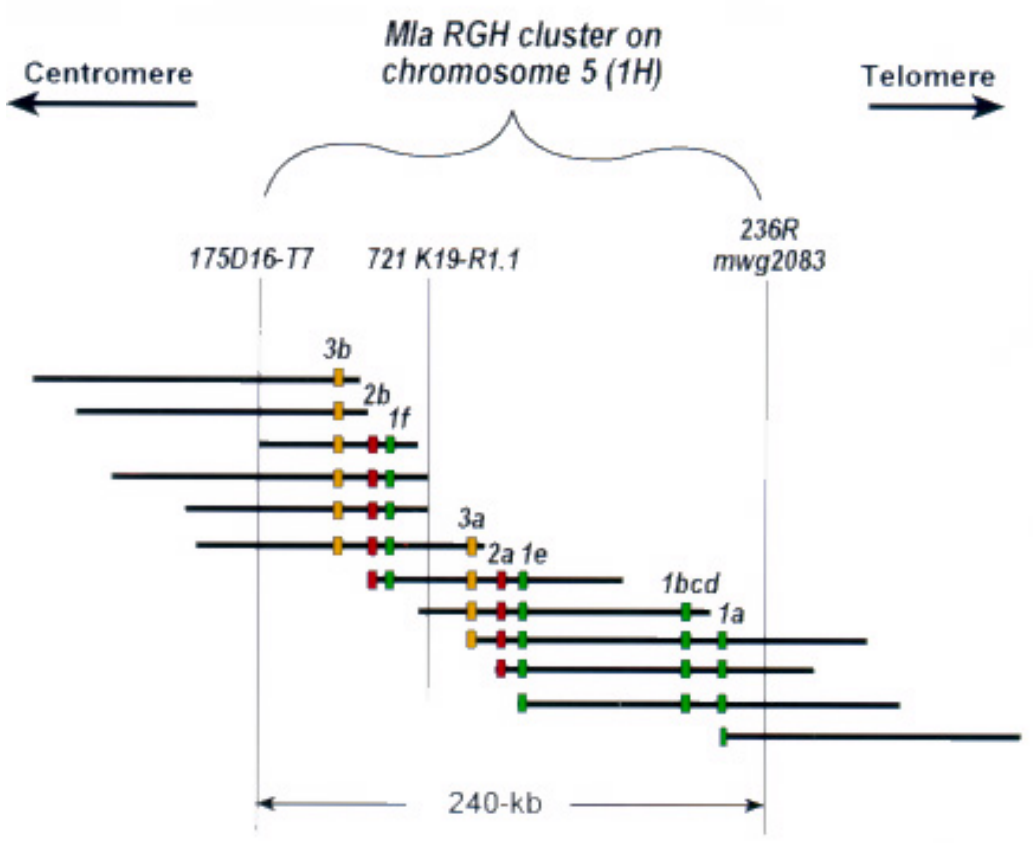

Fig. 4. Overlapping Morex bacterial artificial chromosome (BAC) clones form a complete contiguous DNA sequence that spans the Mla resistance cluster. Distinct BAC clones were used to delineate different members of three nucleotide binding siteleucine-rich repeat, resistant gene homologue (NBS-LRR, $R G H$ ) families. Four members of the RGH1 family (green), two members of the RGH2 family (red), and two members of the $R G H 3$ family (orange) are interspersed within a 240-kb physical interval. The molecular genetic markers 175D16-T7, 721K19-R1.1, and 236R tie the genetic positions on chromosome $5(1 \mathrm{H})$ to physical positions on the BAC contig. 
The availability of numerous mlo mutants facilitated the high-resolution AFLP mapping of the Mlo locus to a 30-kb DNA interval on chromosome $4(4 \mathrm{H})(58)$. The resulting AFLP markers were used to screen a four-genome equivalent YAC library from the cultivar Ingrid, and a subgenomic BAC library was then constructed from the YAC that contained Mlo. The identity of the Mlo gene was inferred by computational analysis of the DNA sequence of a $60-\mathrm{kb}$, Mlo-spanning BAC clone (8). The putative gene deduced by this method was further confirmed by comparison of the DNA sequence to that of
11 mlo mutants. The 533-amino acid, 60$\mathrm{kDa}$ protein is predicted to be anchored by at least six membrane-spanning helices (8). A transient transformation assay was developed to demonstrate that mlo mutants could be complemented at the single cell level. The wild-type Mlo gene and a ubiquitin-GFP (green fluorescent protein) fusion construct were used to simultaneously transform resistant mlo barley by biolistic particle bombardment. Single transformed $M l o-G F P$-fluorescing cells displayed fungal conidiophore development within 6 days after inoculation, indicating complementation of the mutant phenotype (57).
The dissection of broad-spectrum resistance is facilitated by the identification of Ror1 and Ror2 mlo-susceptible mutants. Further analysis of broad-spectrum resistance mediated by mlo currently is being analyzed through the use of mutations in genes that are required for mlospecified resistance (20). These recessive mutants belong to two complementation groups that are not linked to mlo; the loci defined by them have been designated Ror 1 and Ror 2 (Required for $m l \underline{\text { Re-specified }}$ resistance). Seed of plants carrying the mlo-5 allele were mutagenized with EMS (ethyl methanesulfonate) or $\mathrm{NaN}_{3}$ (sodium

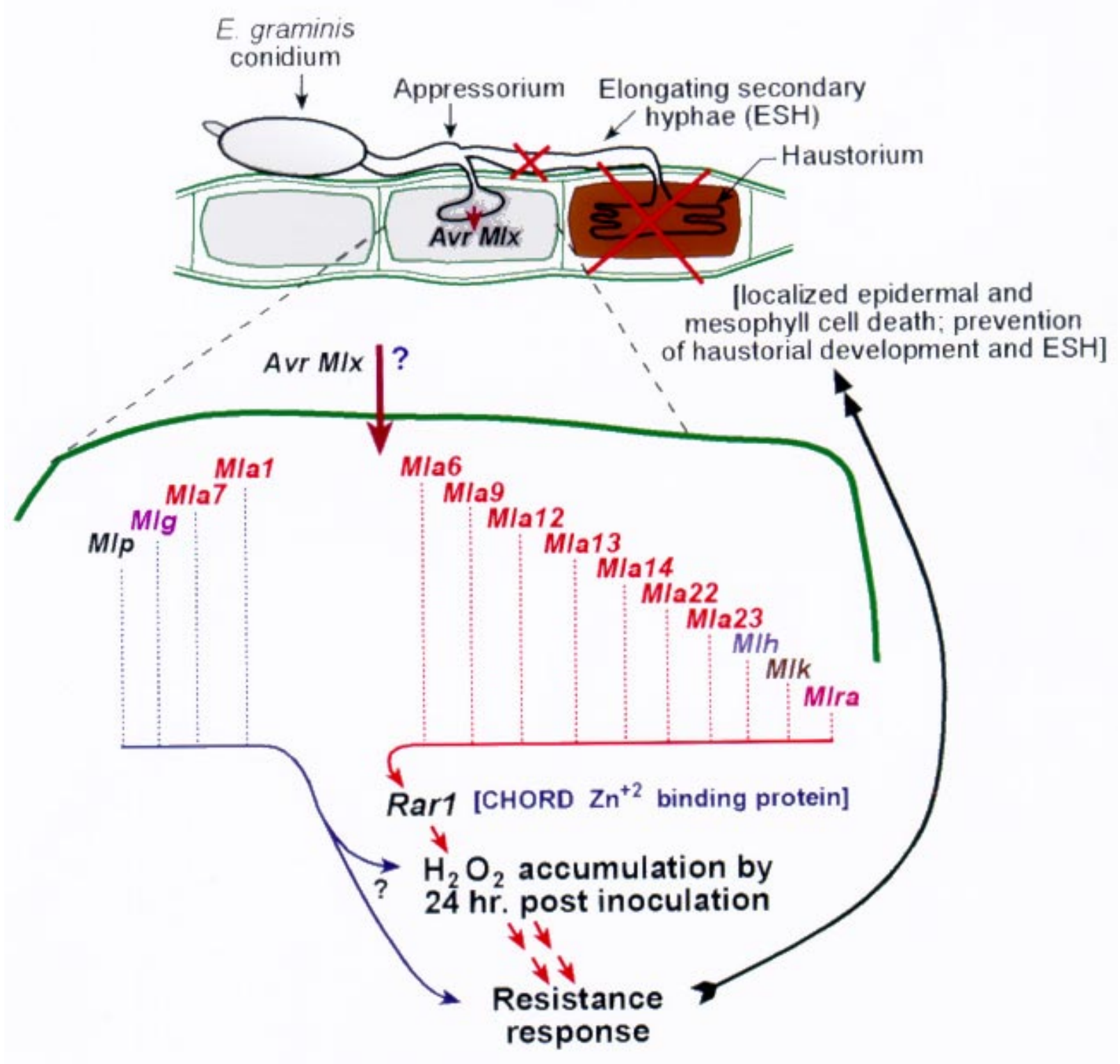

Fig. 5. Model of Ml-mediated resistance interactions. Within $4 \mathrm{~h}$ after an Erysiphe graminis conidium lands on the leaf surface, an appressorium forms; by $12 \mathrm{~h}$ an infection peg initiates leaf surface penetration. By $20 \mathrm{~h}$ postinfection, the infection peg invaginates the plasmalemma and membrane-to-membrane contact is made. The pathogen avirulence elicitor (AvrMIx) interacts with the corresponding host resistance protein and a signal cascade is initiated. The powdery mildew resistance determinants Mla6, Mla9, Mla12, Mla13, Mla14, Mla22, Mla23, MIh, MIk, and MIra signal through Rar1, a $\mathrm{Zn}+$ binding protein; and by $24 \mathrm{~h}$ postinfection, the cell accumulates hydrogen peroxide $\left(\mathrm{H}_{2} \mathrm{O}_{2}\right)$ and dies, inhibiting any further fungal growth. However, Mla1, Mla7, MIg, and MIp do not require Rar1 to function in resistance, indicating that there are at least two $\mathrm{MI}$ signaling pathways. Undoubtedly, there are many more biochemical steps leading to a resistance response. Further characterization of mutations in the resistance pathway will help to clarify these. MIa alleles are shown in red; other independent $M I$ loci are designated by colors other than red. 
azide), and powdery mildew-susceptible mutants were selected from the $\mathrm{M}_{2}$ seedlings. Six mutants were selected from the EMS treatment, and six mutants were derived from the $\mathrm{NaN}_{3}$ treatment. These mutants will be invaluable biological tools to decipher Mlo-gene function.

Freialdenhoven et al. (20) proposed a mechanism in which the Mlo wild-type allele functions as a negative regulator and the Ror genes act as positive regulators of non-race-specific resistance. However, mlo-resistant plants do not confer resistance to Rhynchosporium secalis, a fungal pathogen that, like E. graminis, parasitizes leaf epidermal cells. Likewise, plants carrying mlo alleles are not resistant to barley stem rust or leaf rust, two additional obligate biotrophs that parasitize mesophyll cells (26). Therefore, although mlo alleles are not race specific, they appear to contain some level of pathogen specificity to powdery mildew (20).

Rice as an intergenomic cloning vehicle. Long-distance chromosome walking is not efficient in barley because of the large amount of repetitive DNA and the physical size of the genome. Even genetically close loci may be physically distant. A related species with a smaller genome might be used to isolate a chromosomal region homologous to the target gene. Therefore, another approach to positional cloning in barley has been through the use of rice as an intergenomic cloning vehicle. Rice has the smallest genome of any of the grasses (approximately $430 \mathrm{Mb}$ ) and is highly syntenic with barley $(17,32)$. In addition, the International Rice Genome Sequencing project will provide the complete sequence of the rice genome in the near future; this will complement the Arabidopsis genome sequencing effort to provide the DNA sequence of a monocot as well as a dicot plant species. However, establishment of microsynteny in the target region is essential to exchanging marker information, as small rearrangements are frequent between the rice and barley genomes. Additionally, the very nature of rapid resistance-gene evolution may preclude cloning a resistance gene from rice and using it to identify the corresponding homologous gene from barley. For example, Leister et al. (41) showed that resistance-gene homologues undergo rapid reorganization between barley and rice. Moreover, in attempts to clone the barley Rpgl stem rust resistance gene by using syntenous rice BACs, a contiguous rice sequence was analyzed that contained Rpgl flanking markers; yet no sequence between these markers appeared to be a candidate for an Rpgl homologue $(24,31)$. Therefore, each candidate gene region needs to be assessed on a case-by-case basis. The regions flanking the rpg4 stem rust resistance gene on chromosome $7 \mathrm{~L}$ (5HL) contain significant rearrangements between rice and barley. However, within the $0.5-\mathrm{cM}$ barley region that immediately spans rpg4, the synteny of the markers that cross-hybridize is very uniform $(16,25)$. Thus, rice can be an excellent source of markers for saturation mapping in barley, but caution is warranted when the target gene is involved in coevolution between host and pathogen.

\section{Genome-wide, Structural and Functional Genomics}

Gene-discovery programs traditionally have followed a "one-gene-at-a-time" approach. New genomic tools now allow investigators to take a global approach to gene discovery. Soon, the complete genomic sequencing of two small-genome model plants, Arabidopsis $(120 \mathrm{Mb})$ and rice, will be a reality. In contrast, complete sequencing of large-genome plants is not yet practical, especially for crops with genome sizes well beyond the size of the human genome $(3,000 \mathrm{Mb})$, such as barley
$(5,000 \mathrm{Mb})$ and wheat (16,000 Mb) (3). An alternative solution to gene discovery in such large-genome crop plants is to develop well-characterized, nonredundant EST (expressed sequence tag) resources that define nearly all of the expressed genes. Funded projects in the United States (R. Wing, T. Close, A. Kleinhofs, R. Wise) and Finland (A. Schulman, personal communication) are sequencing 50,000 barley ESTs each. In addition, the IPK group at Gatersleben, Germany, proposes to sequence 100,000 ESTs (A. Graner, personal communication). Each of these projects will sequence ESTs from a variety of tissue sources and developmental stages. Combined, 200,000 ESTs should give a fairly representative view of most of the expressed barley genes. The ESTs then can be arrayed on high-density hybridization filters and subsequently be used to construct microarray profiles on glass slides

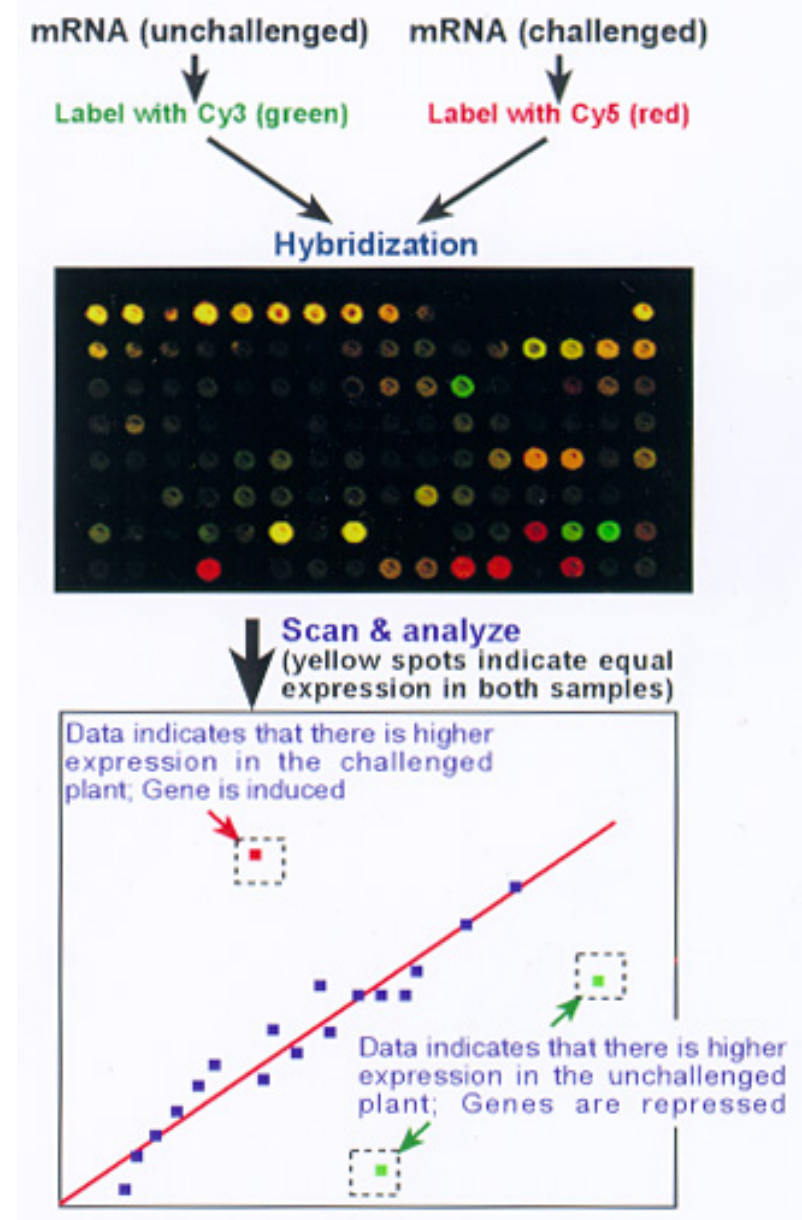

Fig. 6. Global analysis of resistance-mediated gene expression via cDNA microarray. Thousands of sequenced expressed sequence tag (EST) clones are fixed to a glass slide in microarrays. These slides are then available for hybridization with cDNA (derived from plant messenger RNA) that has been isolated after different pathogen treatments and labeled with fluorescent probes. After hybridization, the slide is scanned and analyzed. An EST that displays more green fluorescence than red indicates that that particular message is more prevalent in unchallenged plants than in challenged, or that the gene is repressed. Conversely, a spot that displays more red indicates that the gene is induced in response to the pathogen challenge. ESTs that fluoresce yellow indicate that there is no difference in expression in this comparison. Multiple treatments can be compared, for example, inoculated versus noninoculated, wild-type versus mutant, and 12 versus 24 h postinoculation. 
(12). By utilizing labeled cDNA derived from plant mRNA isolated after different pathogen treatments as a hybridization probe, these microarrays will provide the substrate to analyze simultaneously thousands of expressed sequences in response to pathogen attack (Fig. 6). Furthermore, this global approach will expedite the analysis of genes that are expressed downstream of the initial interactions between host and pathogen in various mutant, dominant, and recessive genotypes. In addition, a proposal has been developed by ITEC (International Triticeae EST Cooperative; http://wheat.pw.usda.gov/genome/) to establish a public database of ESTs from various Triticeae species. The eventual goal of ITEC is to provide sequence data of 300,000 ESTs for wheat and 300,000 ESTs for barley. By the end of July 2000, 24,060 ESTs had been submitted.

Approximately $500 \mathrm{cDNA}$ probes have been mapped in the barley genome $(23,36$; http://wheat.pw.usda.gov/ggpages/maps.ht $\mathrm{ml})$. Genes in barley are roughly colinear with orthologous genes on other closely related grass chromosomes (30), and an anchor set of grass-genome probes has been characterized that is useful for comparative mapping among several Gramineae species (65). As part of the U.S. barley EST project, groups of Morex BAC clones (73) will be identified by batch hybridization of previously mapped and/or anonymous cDNA probes. Since the genetic location of most of these probes is defined, these BAC clone islands will serve to tie the physical map to the genetic map. To make this resource even more useful, probes that are hybridized to the Morex barley BAC library also will be hybridized to a Nipponbare rice BAC library (http://www.genome.clemson.edu/). Nipponbare is the chosen cultivar for the International Rice-Genome Sequencing Project (http://rgp.dna.affrc.go.jp/Seqcollab.html; http://www.genome.clemson.edu/projects/ rice/index.html). These comparative data not only will tie the rice physical map to the barley physical and genetic maps, but by virtue of the colinearity among grass species, will tie the rice genome sequence to other large-genome cereal crops.

\section{Future Prospects}

Substantial progress has been made to understand the molecular basis for disease resistance in cereal crops. Such knowledge is critical for effective utilization of genetic resistance to control plant diseases in the twenty-first century. Historical efforts have provided a wealth of information on the genetics and cytology of disease resistance, and more recently the development of additional research infrastructure in the form of public large-insert (BAC) libraries and microarrays will expedite resistance-gene isolation projects. Although these advances will provide significant insight into these interesting host-pathogen interactions, much remains to be accomplished.

The first of these tools is the continued advancement in DNA marker systems (http://hordeum.oscs.montana.edu/genome/). Cost-effective marker assisted selection is essential for breeding programs to be effective in the development of highyielding, disease-resistant varieties. Furthermore, at least a 10-fold increase in marker density is needed to begin routine map-based gene isolation projects in barley. Currently, these gene-isolation projects are performed "one at a time" and take considerable effort, and the unit cost is quite high.

The second need is for additional creation of several genome-equivalent, largeinsert DNA libraries. High-quality, highdensity libraries are an essential requirement to isolate and study agronomically important genes at the molecular level.

Third, all genome projects have, as an essential component, the analysis of ex- pressed DNA sequence tags (ESTs). The availability of ESTs makes possible the determination of an unknown gene's function by computational analysis of worldwide databases. These databases include genes and proteins from all organisms currently investigated by biologists, including plants, animals, and microbes. Genome-wide scanning of these ESTs via microarray analysis will provide gene expression data from which to determine the mechanisms of resistance signaling of cereal hosts to pathogens. In turn, placement of characterized ESTs on the barley genetic map will provide plant breeders a resource from which to perform efficient marker-assisted selection of chromosomal regions that are important in the resistance response.

Fourth, transformation efficiency needs to be improved. Transformation has been demonstrated in barley and wheat $(42,54,57)$; however, it requires specialized training for routine use, and like many cereal crops, is variety specific. Knowledge of transgenic-gene expression is insufficient, and it is therefore difficult to perform routine transformations for basic and applied research.

Last, but not least, many more additional mutants need to be identified in disease signaling pathways. These mutants will continue to be the foundation for efficient analysis of the molecular features of these genes and will facilitate the understanding of how specific recognition triggers an active defense response. One of the challenges for plant breeders has been that single-gene resistance is often overcome by pathogen mutations that alter the capacity of the host's $R$ genes to recognize the invading pathogen. One approach to solve this problem was to pyramid numerous resistance loci within a single variety either via classical breeding or by marker assisted selection.

As we begin to decipher the different

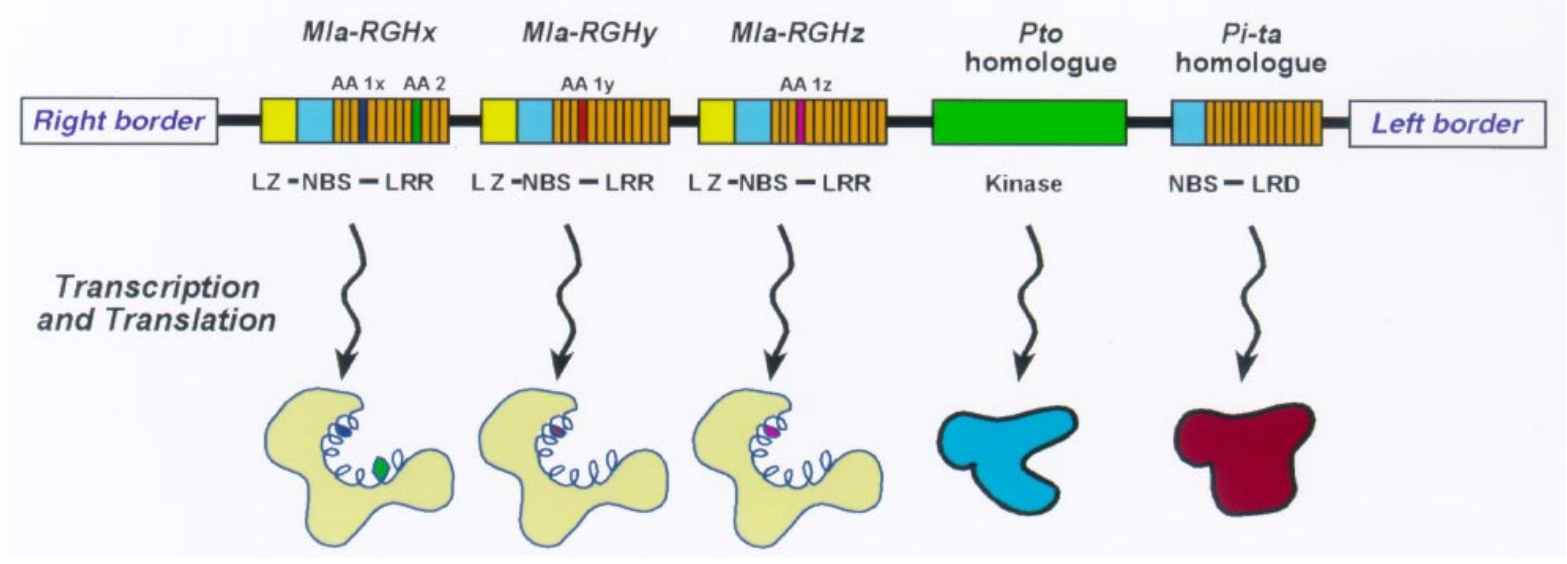

Fig. 7. Molecular pyramiding of different resistance specificities. When multiple independent specificities are characterized via molecular means, they can be coupled together in a cassette for transformation to confer broad-spectrum resistance to different isolates of pathogens. In this hypothetical example, three alleles of the barley Mla locus ( $R G H x$, RGHy, and $R G H z$ ) are coupled together to confer resistance to varied isolates of powdery mildew in addition to resistance conferred by Pto and Pi-ta homologues (see Figure 2). 
variants within a single gene cluster, it will be possible to build molecular pyramids or "cassettes" of different resistance alleles and introduce them into elite lines by direct transformation (Fig. 7). For example, many alleles have been described for various resistance loci in lettuce, tomato, maize, wheat, and flax. In barley, approximately 30 variants have been described for the Mla (powdery mildew resistance) cluster. However, as described earlier, many important resistance loci that have been identified at the genetic level possess multiple highly similar copies at the DNA level. The challenge, therefore, is first to determine the actual sequence of the functional alleles, and second to exploit the sequence similarities among the known alleles to isolate other unknown functional alleles. PCR primers conserved between functional resistance alleles can be utilized to amplify homologous genes from other cultivated or wild barley species and pyramided into a series of DNA vectors for transformation. In many cases, this was previously not possible by traditional methods.

Thus, major efforts have been devoted to the incorporation of genetic resistance in cereal-breeding programs to offset yield loss caused by pathogens. Recently, new technologies have become available for carrying out these investigations at the molecular level. For more information on diseases of small grains, visit the pathology section (http://wheat.pw.usda.gov/ggpages/ pathology.html) of the GrainGenes WWW server at http://wheat.pw.usda.gov/, and the North American Barley Genome Mapping Project (NABGMP) at http://www.css. orst.edu/barley/nabgmp/nabgmp.htm. For additional information on resistance gene sequences on-line, visit the Plant Disease Resistance Genes Data Viewer at http://www.ncgr.org/rgenes/. Finally, information on the Oregon Wolfe barleys, an excellent set of barley lines for instructional uses, is available at http://www.css. orst.edu/barley/wolfebar/wolfnew.htm.

\section{Acknowledgments}

I thank Peggy Lemaux, Andris Kleinhofs, and Paul Schulze-Lefert for important clarifications, Brian Steffenson and Jim Miller for contributions to Figure 1, and Greg Tylka for helpful comments on the manuscript. Research was supported in part by USDA-NRI/CGP grant $98-35300-6170$ and facilitated by the North American Barley Genome Mapping Project. Joint contribution of the Corn Insects \& Crop Genetics Research Unit, USDAAgricultural Research Service, and the Iowa Agriculture and Home Economics Experiment Station. This is Journal Paper J-18643 of the Iowa Agricultural and Home Economics Experiment Station, Ames, Project 3368, and is supported by Hatch Act and State of Iowa funds.

\section{Literature Cited}

1. Anderson, P. A., Lawrence, G. J., Morrish, B. C., Ayliffe, M. A., Finnegan, E. J., and Ellis, J. G. 1997. Inactivation of the flax rust resistance gene $M$ associated with loss of a repeated unit within the leucine-rich repeat coding region. Plant Cell 9:641-651.
2. Anderson, P. A., Okubura, P. A., Arroyogarcia, R., Meyers, B. C., and Michelmore, R. W. 1996. Molecular analysis of irradiation-induced and spontaneous deletion mutants at a disease resistance locus in Lactuca sativa. Mol. Gen. Genet. 251:316-325.

3. Arumuganathan, K., and Earle, E. D. 1991. Nuclear DNA content of some important plant species. Plant Mol. Biol. Rep. 9:208-218.

4. Bachem, C. W., van der Hoeven, R. S., de Bruijn, S. M., Vreugdenhil, D., Zabeau, M., and Visser, R. G. 1996. Visualization of differential gene expression using a novel method of RNA fingerprinting based on AFLP analysis of gene expression during potato tuber development. Plant J. 9:745-753.

5. Baker, B., Zambryski, P., Staskawicz, B., and Dinesh-Kumar, S. P. 1997. Signaling in plantmicrobe interactions. Science 276:726-733.

6. Becker, J., Vos, P., Kuiper, M., Salamini, F., and Heun, M. 1995. Combined mapping of AFLP and RFLP markers in barley. Mol. Gen. Genet. 249:65-73.

7. Bennetzen J. L., SanMiguel, P., Chen, M., Tikhonov, A., Francki, M., and Avramova, Z. 1998. Grass genomes. Proc. Natl. Acad. Sci. USA 95:1975-1978.

8. Büschges, R., Hollricher, K., Panstruga, R., Simons, G., Wolter, M., Frijters, A., van Daelen, R., Groenendijk, J., Topsch, S., Vos, P., Salamini, F., and Schulze-Lefert, P. 1997. The barley Mlo gene: A novel control element of plant pathogen resistance. Cell 88:695-705.

9. Collins, N., Drake, J., Ayliffe, M., Sun, Q., Ellis, J., Hulbert, S., and Pryor, T. 1999. Molecular characterization of the maize $R p 1-D$ rust resistance haplotype and its mutants. Plant Cell 11:1365-1376.

10. Crute, I. R., and Pink, D. A. C. 1996. Genetics and utilization of pathogen resistance in plants. Plant Cell 8:1747-1755.

11. Dempsey, D. A., Silva, H., and Klessig, D. F. 1998. Engineering disease and pest resistance in plants. Trends Microbiol. 6:54-61.

12. DeRisi, J. L., Iyer, V. R., and Brown, P. O. 1997. Exploring the metabolic and genetic control of gene expression on a genomic scale. Science 278:680-686.

13. De Wit, P. J. G. M. 1997. Pathogen avirulence and plant resistance: A key role for recognition. Trends Plant Sci. 12:452-458.

14. Dixon, M. S., Hatzixanthis, K., Jones, D. A., Harrison, K., and Jones, J. D. G. 1998. The tomato $C f-5$ disease resistance gene and six homologs show pronounced allelic variation in leucine-rich repeat copy number. Plant Cell 10:1915-1925.

15. Dixon, M. S., Jones, D. A., Keddie, J. S., Thomas, C. M., Harrison, K., and Jones, J. D. G. 1996. The tomato $C f-2$ disease resistance locus comprises two functional genes encoding leucine-rich repeat proteins. Cell 84:451459.

16. Druka, A., Kudrna, D., Han, F., Kilian, A., Steffenson, B., Yu, Y., Frisch, D., Tomkins, J., Wing, R., and Kleinhofs, A. 1999. Map based cloning of barley rpg 4 gene. Proc. Plant Animal Genome VII Conf.:P391. (http://www.intlpag.org/pag/7/abstracts/posters.html)

17. Dunford, R. P., Kurata, N., Laurie, D. A., Money, T. A., Minobe, Y., and Moorel, G. 1995. Conservation of fine-scale DNA marker order in the genomes of rice and the Triticeae. Nucleic Acids Res. 23:2724-2728.

18. Flor, H. H. 1956. Host-parasite interaction in flax rust - Its genetics and other implications. Phytopathology 45:680-685.

19. Franckowiak, J. 1997. Revised linkage maps for morphological markers in barley, Hordeum vulgare. Barley Genet. Newsl. 26:9-21.

20. Freialdenhoven, A., Peterhänsel, C., Kurth, J., Kreuzaler, F., and Schulze-Lefert, P. 1996. Identification of genes required for the func- tion of non-race-specific mlo resistance to powdery mildew in barley. Plant Cell 8:5-14.

21. Freialdenhoven, A., Scherag, B., Hollricher, K., Collinge, D. B., Thordal-Christensen, H., and Schulze-Lefert, P. 1994. Nar-1 and Nar-2, two loci required for Mla12-specified racespecific resistance to powdery mildew. Plant Cell 6:983-994.

22. Giovannoni, J. J., Wing, R. A., Ganal, M. W. and Tanksley, S. D. 1991. Isolation of molecular markers from specific chromosomal intervals using DNA pools from existing mapping populations. Nucleic Acids Res. 19:6553-6558.

23. Graner, A., Jahoor, A., Schondelmaier, J., Siedler, H., Pillen, K., Fischbeck, G., Wenzel, G., and Hermann, R. G. 1991. Construction of an RFLP linkage map of barley. Theor. Appl. Genet. 83:250-256.

24. Han, F., Kilian, A., Chen, J. P., Kudrna, D. Steffenson, B., Yamamoto, K., Matsumoto, T. Sasaki, T., and Kleinhofs, A. 1999. Sequence analysis of a rice BAC covering the syntenous barley Rpg1 region. Genome 42:1071-1076.

25. Han, F., Kleinhofs, A., Ullrich, S. E., Kilian, A., Yano, M., and Sasaki, T. 1998. Synteny with rice: Analysis of barley malting quality QTLs and rpg4 chromosome regions. Genome 41:373-380.

26. Jørgensen, J. H. 1977. Spectrum of resistance conferred by Mlo powdery mildew resistance genes in barley. Euphytica 26:55-62.

27. Jørgensen, J. H. 1994. Genetics of powdery mildew resistance in barley. Genome 13:97-119.

28. Jørgensen, J. H. 1996. Effect of three suppressors on the expression of powdery mildew resistance genes in barley. Genome 39:492-498.

29. Kanazin, V., Marek, L. F., and Shoemaker, R. C. 1996. Resistance gene analogs are conserved and clustered in soybean. Proc. Natl. Acad. Sci. USA 93:11751-11756.

30. Keller, B., and Feuillet, C. 2000. Colinearity and gene density in grass genomes. Trends Plant Sci. 5:246-251.

31. Kilian, A., Chen, J., Han, F., Steffenson, B., and Kleinhofs, A. 1997. Towards map-based cloning of the barley stem rust resistance genes Rpg1 and rpg4 using rice as an intergenomic cloning vehicle. Plant Mol. Biol. 35:187-195.

32. Kilian, A., Kudrna, D. A., Kleinhofs, A., Yano, M., Kurata, K., Steffenson, B., and Sasaki, T. 1995. Rice-barley synteny and its application to saturation mapping of the barley Rpg1 region. Nucleic Acids Res. 23:27292733.

33. Kleine, M., Michalek, W., Diefenthal, T., Dargatz, H., and Jung, C. 1997. Construction of a MluI-YAC library from barley (Hordeum vulgare L.) and analysis of YAC insert terminal regions. Genome 40:896-902.

34. Kleine, M., Michalek, W., Graner, A., Herrmann, R. G., and Jung, C. 1993. Construction of a barley (Hordeum vulgare $\mathrm{L}$.) YAC library and isolation of a Horl-specific clone. Mol. Gen. Genet. 240:265-272.

35. Kleinhofs, A., and Graner, A. 2000. An integrated map of the barley genome. In: DNABased Markers in Plants, 2nd ed. R. L. Phillips and I. K. Vasil, eds. Kluwer Academic Publishers, Dordrecht, Netherlands.

36. Kleinhofs, A., Kilian, A., Saghai Maroof, M. A., Biyashev, R. M., Hayes, P., Chen, F. Q., Lapitan, N., Fenwick, A., Blake, T. K., Kanazin, V., Ananiev, E., Dahleen, L., Kudrna, D. Bollinger, J., Knapp, S. J., Liu, B., Sorrells, M., Heun, M., Franckowiak, J. D., Hoffman, D., Skadsen, R., and Steffenson, B. J. 1993. A molecular, isozyme and morphological map of the barley (Hordeum vulgare) genome. Theor. Appl. Genet. 86:705-712.

37. Koprek, T., Cho, M.-J., Choi, H. W., Kim, H. K., Zhang, S., Bregitzer, P., and Lemaux, P. G 


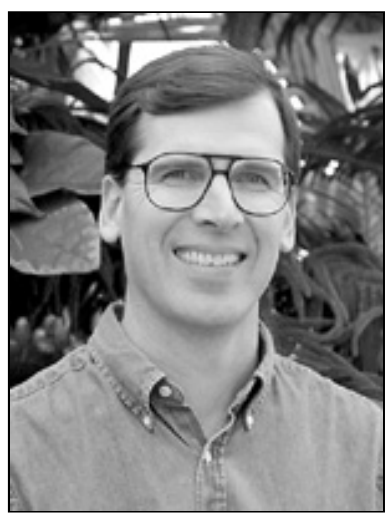

Roger P. Wise

Dr. Wise is a Research Geneticist with the USDA-Agricultural Research Service and a Professor of Plant $\mathrm{Pa}$ thology at lowa State University. He is active in the Interdepartmental Genetics graduate program and is a member of the Center for Plant Responses to Environmental Stresses (CPRES), the Center for Plant Genomics (PGC), and the Center for Plant Transformation and Gene Expression within the ISU Plant Sciences Institute. He obtained his Ph.D. in genetics from Michigan State University followed by postdoctoral research at the University of Florida and the Max-PlanckInstitut für Züchtungsforschung in Köln, Germany. His research is focused on the molecular mechanisms of host resistance to obligate biotrophs in cereals as well as cytoplasmic male sterility and fertility restoration in maize.

1999. Clearing the hurdles of small grain transformation: A molecular and cytological approach. Pages 2.3.1-2.3.8 in: Proc. Aust. Barley Tech. Sympos., 9th. Melbourne, Victoria, Australia.

38. Kumar, A. 1996. The adventures of Ty1-copia group of retrotransposons in plants. Trends Genet. 12:41-43

39. Lahaye, T., Shirasu, K., and Schulze-Lefert, P. 1998. Chromosome landing at the barley Rarl locus. Mol. Gen. Genet. 260:92-101.

40. Lawrence, G. J., Finnegan, E. J., Ayliffe, M. A., and Ellis, J. G. 1995. The L6 gene for flax rust resistance is related to the Arabidopsis bacterial resistance gene RPS 2 and the tobacco viral resistance gene $N$. Plant Cell 7:1195-1206.

41. Leister, D., Kurth, J., Laurie, D. A., Yano, M., Sasaki, T., Devos, K., Graner, A., and Schulze-Lefert, P. 1997. Rapid reorganization of resistance gene homologues in cereal genomes. Proc. Natl. Acad. Sci. USA 95:370375 .

42. Lemaux, P. G., Cho, M.-J., Zhang, S., and Bregitzer, P. 1999. Transgenic cereals: Hordeum vulgare L. (barley). Pages 255-316 in: Molecular Improvement of Cereal Crops. I. K. Vasil, ed. Kluwer Academic Publishers, Dordrecht, Netherlands.

43. Maes, T., De Keukeleire, P., and Gerats, T. 1999. Plant tagnology. Trends Plant Sci. 4:90-96.
44. McElroy, D., Louwerse, J., McElroy, S., and Lemaux, P. G. 1997. Development of a simple transient assay for $A c-D s$ activity in cells of intact barley tissue. Plant J. 11:157-165.

45. Meyers, B. C., Chin, D. B., Shen, K. A., Sivaramakrishnan, S., Lavelle, D. O., Zhang, Z., and Michelmore, R. W. 1998. The major resistance gene cluster in lettuce is highly duplicated and spans several megabases. Plant Cell 10:1817-1832

46. Meyers, B. C., Shen, K. A., Rohani, P., Gaut, B. S., and Michelmore, R. W. 1998. Receptorlike genes in the major resistance locus of lettuce are subject to divergent selection. Plant Cell 10:1833-1846.

47. Michelmore, R. 1995. Molecular approaches to manipulation of disease resistance genes. Annu. Rev. Phytopathol. 15:393-427.

48. Michelmore, R. W., and Meyers, B. C. 1998. Clusters of resistance genes evolve by divergent selection and a birth and death process. Genome Res. 8:1113-1130.

49. Michelmore, R. W., Paran, I., and Kesseli, R. V. 1991. Identification of markers linked to disease-resistance genes by bulked segregant analysis: A rapid method to detect markers in specific genomic regions by using segregating populations. Proc. Natl. Acad. Sci. USA 88:9828-9832.

50. Parniske, M., Hammond-Kosack, K. E., Golstein, C., Thomas, C. M., Jones, D. A., Harrison, K., Wulff, B. H., and Jones, J. D. G. 1997. Novel disease resistance specificity's result from sequence exchange between tandemly repeated gene at the $C f-4 / 9$ locus of tomato. Cell 91:821-832.

51. Ronald, P. C. 1998. Resistance gene evolution. Curr. Opinions Biol. 1:294-298.

52. Salmeron, J. M., Oldroyd, G. E. D., Rommens, C. M. T., Scofield, S. R., Kin, H.-S., Lavelle, B. T., Dahlbech, D., and Staskawicz, B. J. 1996. Tomato Prf is a member of the leucine-rich repeat class of disease resistance genes and lies embedded within the Pto kinase gene cluster. Cell 86:123-133.

53. SanMiguel, P., Tikhonov, A., Jin, Y. K., Motchoulskaia, N., Zakharov, D., MelakeBerhan, A., Springer, P. S., Edwards, K. J., Lee, M., Avramova, Z., and Bennetzen, J. L. 1996. Nested retrotransposons in the intergenic regions of the maize genome. Science 274:765-768.

54. Schweizer, P., Pokorny, J., Abderhalden, O., and Dudler, R. A. 1999. Transient assay system for the functional assessment of defenserelated genes in wheat. Mol. Plant-Microbe Interact. 12:647-654

55. Shen, K. A., Meyers, B. C., Islam-Faridi, M. N., Chin, D. B., Stelly, D. M., and Michelmore, R. W. 1998. Resistance gene candidates identified by PCR with degenerate oligonucleotide primers map to clusters of resistance genes in lettuce. Mol. Plant-Microbe Interact. 11:815-823.

56. Shirasu, K., Lahaye, T., Tan, M., Zhou, F., Azevedo, C., and Schulze-Lefert, P. 1999. A novel class of eukaryotic zinc-binding proteins is required for disease resistance signaling in barley and development in C. elegans. Cell 99:355-366.

57. Shirasu, K., Nielsen, K., Piffanelli, P., Oliver, R., and Schulze-Lefert, P. 1999. Cell-autonomous complementation of mlo resistance using a biolistic transient expression system. Plant J. 17:293-299.

58. Simons, G., van der Lee, T., Diergaarde, P., van Daelen, R., Groenendijk, J., Frijters, A., Büschges, R., Hollricher, K., Töpsch, S., Schulze-Lefert, P., Salamini, F., Zabeau, M., and Vos, P. 1997. AFLP-based fine mapping of the Mlo gene to a 30-kb DNA segment of the barley genome. Genomics 44:61-70.

59. Song, W. Y., Pi, L. Y., Wang, G. L., Gardner, J., Holsten, T., and Ronald, P. C. 1997. Evolution of the rice $\mathrm{Xa} 21$ disease resistance gene family. Plant Cell 9:1279-1287.

60. Song, W. Y., Wang, G. L., Chen, L. L., Kim, H. S., Pi, L. Y., Holsten, T., Gardner, J., Wang, B., Zhai, W. X., Zhu, L. H., Fauquet, C., and Ronald, P. 1995. A receptor kinase-like protein encoded by the rice disease resistance gene, Xa21. Science 270:1804-1806.

61. Suoniemi, A., Anamthawat-Jonsson, K., Arna, T., and Schulman, A. H. 1996. Retrotransposon BARE-1 is a major, dispersed component of the barley (Hordeum vulgare L.) genome. Plant Mol. Biol. 30:1321-1329.

62. Tanksley, S. D., Martin, W., Ganal, M. W., and Martin, G. B. 1995. Chromosome landing, a paradigm for map based gene cloning with large genomes. Trends Genet. 11:63-68.

63. Thomas, C. M., Vos, P., Zabeau, M., Jones, D. A., Norcott, K. A., Chadwick, B. P., and Jones, J. D. G. 1995. Identification of amplified restriction fragment polymorphism (AFLP) markers tightly linked to the tomato Cf-9 gene for resistance to Cladosporium fulvum. Plant J. 8:785-794.

64. Torp, J., and Jørgenson, J. H. 1986. Modification of barley powdery mildew resistance gene Mla12 by induced mutation. Can. J. Genet. Cytol. 28:725-731.

65. Van Deynze, A. E., Sorrells, M. E., and McCouch, S. R. 1998. Anchor probes for comparative mapping of grass species. Cornell University. (http://greengenes.cit. cornell.edu:80/anchors/)

66. Vicient, C. M., Suoniemi, A., AnamthawatJónsson, K., Tanskanena, J., Beharavc, A. Nevoc, E., and Schulman, A. H. 1999. Retrotransposon BARE-1 and its role in genome evolution in the genus Hordeum. Plant Cell 11:1769-1784.

67. Vos, P., Hogers, R., Bleeker, M., Reijans, M., Lee, T., van de Hornes, M., Fritjers, A., Pot, J., Peleman, J., Kuiper, M., and Zabeau, M. 1995. AFLP: A new technique for DNA fingerprinting. Nucleic Acids Res. 23:4407-4414.

68. Walbot, V. 1992. Strategies for mutagenesis and gene cloning using transposon tagging and T-DNA insertion mutagenesis. Annu. Rev. Plant Physiol. Plant Mol. Biol. 43:49-82.

69. Waugh, R., McLean, K., Flavell, A. J., Pearce, S. R., Kumar, A., Thomas, B. B. T., and Powell, W. 1997. Genetic distribution of Bare-1like retrotransposable elements in the barley genome revealed by sequence-specific amplification polymorphism (S-SAP). Mol. Gen. Genet. 253:687-694.

70. Wei, F., Gobelman-Werner, K., Morroll, S M., Kurth, J., Mao, L., Wing, R., Leister, D. Schulze-Lefert, P., and Wise, R. P. 1999. The Mla (powdery mildew) resistance cluster is associated with three NBS-LRR gene families and suppressed recombination within a 240 kb DNA interval on chromosome 5S (1HS) of barley. Genetics 153:1929-1948.

71. Yu, G. X., and Wise, R. P. 2000. An anchored AFLP and retrotransposon-based map of diploid Avena. Genome 43:736-749.

72. Yu, Y., Buss, G. R., and Saghai Maroof, M. A 1996. Isolation of a superfamily of candidate resistance genes in soybean based on conserved nucleotide-binding site. Proc. Natl. Acad. Sci. USA 93:11746-11750.

73. Yu, Y., Tomkins, J. P., Waugh, R., Frisch, D. A., Kudrna, D., Kleinhofs, A., Brueggeman, R. S., Muehlbauer, G. J., Wise, R. P., and Wing, R. A. A bacterial artificial chromosome library for barley (Hordeum vulgare L.) and the identification of clones containing putative resistance genes. Theor. Appl. Genet. In press. 